\title{
Pengaruh Theory Of Planned Behavior Terhadap Minat Kewirausahaan Mahasiswa Universitas Tarumanagara
}

\author{
Felya dan Herlina Budiono \\ Program Studi S1 Manajemen Fakultas Ekonomi Universitas Tarumanagara, Jakarta \\ Email:felya.ng@yahoo.com; herlinab@fe.untar.ac.id
}

\begin{abstract}
The purpose of this study is to find out 1) whether there is an effect of Attitude on Entrepreneurship Intention, 2) whether there is an influence of the Subjective Norms on Entrepreneurship Intention, 3) whether there is an influence of Perceived Behavioral Control on Entrepreneurship Intention, 4) whether there is an influence of Short term Risk Taking on Entrepreneurship Intention, 5) whether there is an influence of Psychological Wellbeing on Entrepreneurship Intention. The population in this study were students of the Faculty of Economics, Tarumanagara University, class of 2015 -2018. The sample used in this study was 100 respondents from the Students of the Faculty of Management Economics, Tarumanagara University. The sampling technique used was nonprobability sampling with purposive sampling method. Overall the results of this study are 1) Attitude has a significant effect and positively to Entrepreneurship Intention in Tarumanagara University Faculty of Economics Management Students, 2) Subjective Norms do not significantly influence but remain positive towards Entrepreneurship Intention in Tarumanagara University Faculty of Economics Management Students, 3) Perceived Behavioral Control has a significant effect and positively to Entrepreneurship Intention in Tarumanagara University Faculty of Economics Management Students, 4) Short term Risk Taking has a significant effect and positively to Entrepreneurship Intention in Tarumanagara University Faculty of Economics Management Students, 5) Psychological Wellbeing has a significant effect and positively to Entrepreneurship Intention in Tarumanagara University Faculty of Economics Management Students.
\end{abstract}

Keywords: Theory of Planned Behavior, Psychological Well-being, Short term Risk Taking, Entrepreneurship Intention.

Abstrak: Tujuan penelitian ini adalah untuk mengetahui 1) apakah terdapat pengaruh Sikap terhadap Minat Kewirausahaan, 2) apakah terdapat pengaruh Norma Subjektif terhadap Minat Kewirausahaan, 3) apakah terdapat pengaruh Persepsi Kontrol Perilaku terhadap Minat Kewirausahaan, 4) apakah terdapat pengaruh Pengambilan Risiko Jangka Pendek terhadap Minat Kewirausahaan, 5) apakah terdapat pengaruh Kesejahteraan Psikologis terhadap Minat Kewirausahaan. Populasi dalam penelitian ini adalah Mahasiswa Fakultas Ekonomi Universitas Tarumanagara angkatan 2015-2018. Sampel yang digunakan pada penelitian ini yaitu 100 responden Mahasiswa Fakultas Ekonomi Manajemen Universitas Tarumanagara. Teknik pengambilan sampel yang digunakan yaitu non probability sampling dengan metode pengambilan sampel purposive sampling. Secara keseluruhan hasil dari penelitian ini yaitu 1) Sikap berpengaruh signifikan dan positif terhadap Minat Kewirausahaan Mahasiswa Fakultas Ekonomi Manajemen Universitas Tarumanagara, 2) Norma Subjektif tidak berpengaruh secara signifikan namun tetap positif terhadap Minat Kewirausahaan Mahasiswa Fakultas Ekonomi Manajemen Universitas Tarumanagara, 3) 
Persepsi Kontrol Perilaku berpengaruh signifikan dan positif terhadap Minat Kewirausahaan Mahasiswa Fakultas Ekonomi Manajemen Universitas Tarumanagara, 4) Pengambilan Risiko Jangka Pendek berpengaruh positif dan signifikan terhadap Minat Kewirausahaan Mahasiswa Fakultas Ekonomi Manajemen Universitas Tarumanagara, 5) Kesejahteraan Psikologis berpengaruh positif dan signifikan terhadap Minat Kewirausahaan Mahasiswa Fakultas Ekonomi Manajemen Universitas Tarumanagara.

Kata kunci: Theory of Planned Behavior, Kesejahteraan Psikologis, Pengambilan Risiko Jangka Pendek, Minat Kewirausahaan.

\section{LATAR BELAKANG}

Pengangguran dan kemiskinan merupakan masalah klasik yang dihadapi oleh negaranegara berkembang termasuk Indonesia. Pengangguran mempunyai dampak yang serius terhadap kondisi perekonomian negara, karena pengangguran dapat mengakibatkan depresi atau menimbulkan keputusasaan pada generasi muda yang berujung pada meningkatnya tingkat kriminalitas maupun penggunaan obat-obatan terlarang. Terdapat beberapa faktor yang menyebabkan terjadinya pengangguran, yakni angkatan kerja yang lebih besar daripada kesempatan kerja, kualifikasi tenaga kerja yang tidak sesuai dengan persyaratan jabatan, pemutusan hubungan kerja, efektivitas informasi dan mekanisme pasar kerja yang belum optimal, serta krisis global.

Untuk mengatasi masalah pengangguran yang ada, perlu dikembangkan beberapa solusi, salah satunya adalah mendukung kegiatan kewirausahaan mikro terutama di kalangan generasi muda. Dengan didukung oleh program pemerintah dan berkembangnya bidang kewirausahaan, menjadi seorang wirausaha sudah menjadi pilihan karier yang populer sejak beberapa tahun belakangan ini.

Kegiatan wirausaha pada dasarnya lahir dari dimulainya minat kewirausahaan. Minat kewirausahaan juga dipengaruhi oleh beberapa faktor lainnya yang telah diteliti secara mendalam pada penelitian sebelumnya, mulai dari faktor budaya, gender, pengaruh keluarga, persepsi kemampuan individu, kepercayaan, halangan masuk, pengetahuan dan keahlian, pendidikan, sampai dengan pengaruh orang tua.

Ada beberapa pendekatan untuk mempelajari minat kewirausahaan, salah satunya adalah Theory of Planned Behavior yang sudah banyak diterapkan untuk mempelajari minat individu. Teori ini mengklaim bahwa sikap, norma subjektif, dan persepsi kontrol perilaku mampu memprediksi minat individu untuk bertindak.

Sikap merupakan kecenderungan untuk menanggapi hal-hal yang disenangi ataupun yang tidak disenangi pada suatu peristiwa ataupun objek. Sikap dianggap sebagai variabel pertama yang mempengaruhi minat seseorang dalam berperilaku. Pandangan tentang suatu sikap dipengaruhi oleh keyakinan sebagai akibat dari tingkah laku yang dilakukan. Pandangan atas sikap diyakini mempunyai dampak langsung terhadap kehendak individu untuk berperilaku yang kemudian diafiliasikan dengan norma subjektif.

Norma subjektif adalah keyakinan individu akan norma, orang sekitarnya dan motivasi individu untuk mengikuti norma tersebut. Norma subjektif menangkap pengaruh sosial untuk melakukan atau tidak melakukan tindakan kewirausahaan. Hal ini merupakan penentu penting bagi individu yang belum memiliki pengalaman dalam bidang kewirausahaan. 
Dari aspek persepsi kontrol perilaku, peneliti telah mengeksplorasi keberhasilan diri dalam mengukur keterampilan berbisnis dan menguji pengaruhnya terhadap minat kewirausahaan. Persepsi kontrol perilaku mencerminkan sumber daya dan peluang yang diyakini individu dapat mereka peroleh ataupun mereka kembangkan untuk memulai bisnis mereka.

Kegiatan kewirausahaan adalah upaya yang berisiko secara alami, dan menghadapi risiko merupakan bagian utama dari minat kewirausahaan. Namun aspek ini tidak termasuk dalam Theory of Planned Behavior yang asli. Risiko menggambarkan preferensi terhadap ketidakpastian dengan distribusi kemungkinan di atas kepastian. Penelitian telah menunjukkan bahwa sikap positif terhadap risiko atau kesediaan untuk memberikan hasil yang tidak pasti dapat dikaitkan dengan minat kewirausahaan.

Preferensi pengambilan risiko jangka panjang dan jangka pendek menangkap fitur dasar dari kecenderungan dan persepsi risiko. Ketika pengusaha memulai bisnis baru, mereka memiliki preferensi yang berbeda antara pengambilan risiko jangka panjang dan jangka pendek. Misalnya, jika pengusaha memulai bisnis dimana mereka bersedia menanggung ketidakpastian kinerja dalam jangka waktu pendek (seperti satu tahun), maka mereka cenderung mengambil risiko jangka pendek. Dampak positif dari preferensi pengambilan risiko jangka pendek pada minat kewirausahaan cenderung berada di samping dampak dari norma subjektif, sikap dan persepsi kontrol perilaku yang merupakan bagian dari Theory of Planned Behavior.

Kesejahteraan psikologis menggambarkan emosi positif individu tentang keseluruhan fungsi kemanusiaan individu. Para peneliti dari bidang psikologi percaya bahwa individu dengan kesejahteraan psikologis yang kuat cenderung memiliki tingkatan sikap positif yang lebih tinggi, yang membuat individu menjalani kehidupannya secara lebih bermakna sehingga individu mampu menyelesaikan masalah dengan baik. Hal ini menguntungkan individu karena mampu menangani situasi krisis dengan lancar. Dalam konteks kewirausahaan, peneliti telah mempelajari praktik kewirausahaan yang dapat meningkatkan kesejahteraan psikologis individu. Dengan demikian, kesejahteraan psikologis dapat memengaruhi minat kewirausahaan di samping sikap, norma subjektif dan persepsi kontrol perilaku.

\section{KAJIAN TEORI}

Theory of Planned Behavior (TPB) sangat sesuai jika digunakan untuk menjelaskan berbagai perilaku dalam bidang kewirausahaan. Teori perilaku aktual (Ajzen, 1991) atau Theory of Planned Behavior merupakan perluasan dari Theory of Reasoned Action (TRA).

TRA awalnya diperkenalkan oleh Fishbein pada tahun 1967. Seiring berjalannya waktu, teori tersebut disempurnakan selama bertahun-tahun oleh Fishbein dan Ajzen (1975) karena mereka menyadari bahwa individu memiliki kendala dalam mewujudkan perilakunya, meskipun individu yang bersangkutan telah memiliki niat untuk mewujudkan perilaku tersebut. Teori ini juga menegaskan sikap normatif yang mungkin dimiliki oleh seseorang tentang apa yang akan dilakukan orang lain pada situasi yang sama. Minat untuk berperilaku ditentukan oleh dua faktor utama, yaitu sikap dan norma subjektif. Pada tahun 1991, Ajzen mengembangkan TRA dengan menambahkan sebuah variabel persepsi pengendalian perilaku, teori tersebut dikenal dengan Theory of Planned Behavior (TPB).

Menurut Gagne dan Briggs (1979), sikap merupakan suatu keadaan internal yang mempengaruhi pilihan tindakan individu terhadap objek, orang atau kejadian tertentu. Sikap 
merupakan kecenderungan kognitif, afektif, dan tingkah laku yang dipelajari untuk berespons secara positif maupun negatif terhadap objek, situasi, institusi, konsep atau seseorang. Ajzen (2006) menyatakan bahwa sikap terhadap perilaku merupakan suatu fungsi yang didasarkan oleh behavioral beliefs, yaitu belief seseorang terhadap konsekuensi positif atau negatif yang akan diperoleh seseorang apabila melakukan suatu perilaku.

Menurut Maulana, H.D (2009:58), norma subjektif merujuk pada "keyakinan seseorang tentang bagaimana dan apa yang harus dipikirkan tentang orang yang dianggap penting dan termotivasi untuk mengikuti pemikiran tersebut." Menurut Ramdhani (2011): "Norma subjektif adalah persepsi individu terhadap harapan dari orang-orang yang berpengaruh dalam kehidupannya mengenai dilakukan atau tidak dilakukannya perilaku tertentu. Persepsi ini sifatnya subjektif sehingga dimensi ini disebut norma subjektif ".

Ismail dan Zain (2008) berpendapat bahwa persepsi kontrol perilaku merupakan "persepsi individu mengenai kontrol yang dimiliki individu tersebut sehubungan dengan tingkah laku tertentu". Menurut Ajzen (2006), persepsi kontrol perilaku diartikan sebagai fungsi yang didasarkan pada control beliefs, yaitu belief seseorang tentang ada atau tidak adanya faktor pendukung atau penghambat untuk dapat memunculkan suatu perilaku.

Menurut Kisker dan Ernst (2015), keinginan untuk mengambil risiko merupakan salah satu kunci utama dalam berwirausaha. Seorang pengusaha yang memulai bisnis baru dengan motivasi yang tinggi untuk fleksibilitas dan kebebasan diri tentunya akan berani mengambil risiko yang lebih besar dan meningkatkan pengeluaran dalam bisnisnya. Menurut Zuckerman (1984), pengambilan risiko merupakan salah satu bagian dari mencari sensasi, yang artinya sebagai suatu sifat yang menggambarkan kecenderungan orang untuk mencari berbagai macam sensasi dan pengalaman baru secara konsisten dan kompleks serta kesediaan untuk mengambil risiko.

Menurut Lawton (1983), kesejahteraan psikologis merupakan gambaran seseorang mengenai hidup yang berkualitas yang dianggap baik atau memuaskan. Ryff (1989) menyatakan bahwa kesejahteraan psikologis adalah suatu keadaan dimana individu mampu menerima dirinya apa adanya, mampu membentuk hubungan yang hangat dengan orang lain, memiliki kemandirian terhadap tekanan dalam hidupnya, mampu mengontrol lingkungan, memiliki arti hidup serta mampu merealisasikan potensi dirinya secara berkelanjutan.

Menurut Kartz dan Gartner (1998), minat kewirausahaan dapat diartikan sebagai proses pencarian informasi yang dapat digunakan untuk mencapai tujuan pembentukan suatu usaha. Seseorang dengan minat kewirausahaan akan memiliki kesiapan dan kemajuan yang lebih baik dalam usaha yang dijalankan dibandingkan seseorang tanpa minat kewirausahaan. Menurut Aris Subandono (2007:18), minat kewirausahaan adalah "kecenderungan hati dalam diri subjek untuk tertarik menciptakan suatu usaha yang kemudian mengatur, menanggung, mengorganisir, menanggung resiko, dan mengembangkan usaha yang diciptakannya tersebut".

Kerangka Pemikiran dalam peneletian ini seperti yang digambarkan dibawah ini: 


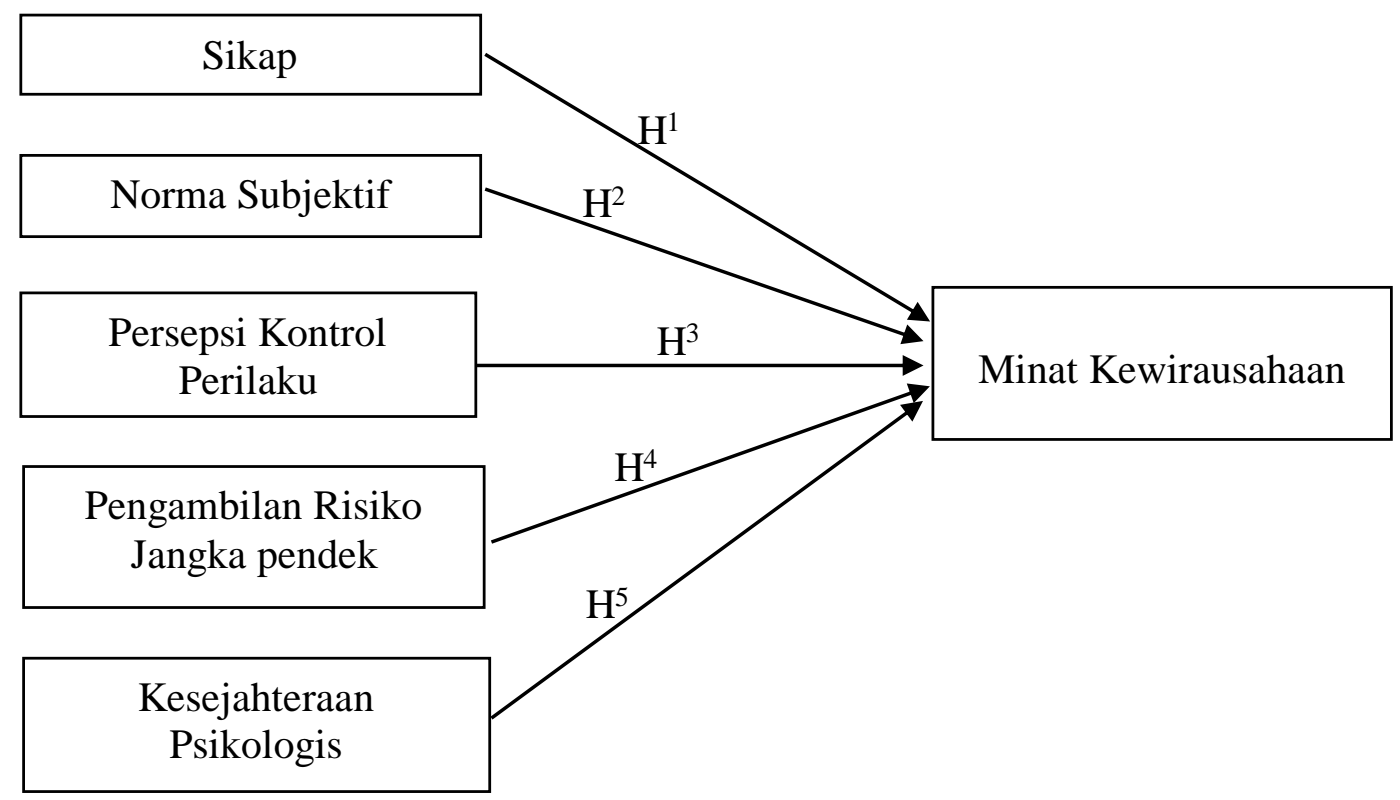

Gambar 1. Kerangka Pemikiran

Hipotesis dari model yang dibangun di atas adalah sebagai berikut:

$\mathrm{H}_{1}$ : Terdapat pengaruh Sikap dengan Minat Kewirausahaan pada mahasiswa Fakultas Ekonomi Manajemen Universitas Tarumanagara.

$\mathrm{H}_{2}$ : Terdapat pengaruh Norma Subjektif dengan Minat Kewirausahaan pada mahasiswa Fakultas Ekonomi Manajemen Universitas Tarumanagara.

$\mathrm{H}_{3}$ : Terdapat pengaruh Persepsi Kontrol Perilaku dengan Minat Kewirausahaan pada mahasiswa Fakultas Ekonomi Manajemen Universitas Tarumanagara.

$\mathrm{H}_{4}$ : Terdapat pengaruh Pengambilan Risiko Jangka Pendek dengan Minat Kewirausahaan pada mahasiswa Fakultas Ekonomi Manajemen Universitas Tarumanagara.

H5 : Terdapat pengaruh Kesejahteraan Psikologis dengan Minat Kewirausahaan pada mahasiswa Fakultas Ekonomi Manajemen Universitas Tarumanagara.

\section{METODOLOGI}

Menurut Keringler (1986), desain penelitian dapat didefinisikan sebagai rencana, struktur, dan strategi penyelidikan yang hendak dilakukan peneliti untuk mendapatkan jawaban dari pertanyaan atau permasalahan penelitian, dimana rencana tersebut merupakan skema atau program lengkap dari sebuah penelitian, mulai dari penyusunan hipotesis yang berimplikasi pada cara, prosedur penelitian dan pengumpulan data sampai dengan analisis data. Dengan adanya desain penelitian, peneliti juga dapat memilah data yang sesuai dengan topik penelitian dan data yang tidak sesuai dengan topik penelitian.

Penelitian ini menggunakan metode penelitian kuantitatif yang bertujuan untuk menjelaskan menentukan hubungan antar variabel dalam sebuah populasi. Selain itu, tujuan penelitian ini adalah melakukan pengujian untuk mengetahui apakah variabel independen 
memiliki pengaruh terhadap variabel dependen. Dalam penelitian kuantitatif, data set dikumpulkan, diolah, lalu kemudian dianalisis untuk dicari hubungan antar variabel yang diteliti.

Populasi yang digunakan sebagai subjek penelitian ini adalah mahasiswa Fakultas Ekonomi Universitas Tarumangara angakatan 2015-2018. Untuk itu, dalam kuisioner yang akan dibagikan ditulis sebagai berikut: "Pengaruh Theory of Planned Behavior terhadap Minat Kewirausahaan mahasiswa Fakultas Ekonomi Manajemen Universitas Tarumangara".

Teknik pemilihan sampel yang digunakan dalam penelitian ini adalah teknik tak acak purposive. Teknik ini digunakan atas dasar kemudahan unsur populasi untuk dijangkau. Untuk itu, unsur populasi yang lebih mudah dapat diperoleh datanya untuk itu unsur itulah yang dapat dijadikan sampel.

Jenis data yang dapat digunakan dalam penelitian ini adalah data primer. Data primer adalah seluruh data yang telah dikumpulkan sendiri oleh peneliti agar dapat menjawab suatu permasalahan penelitiannya.

Skala Likert dinyatakan sebagai skala nominal karena alternatif tanggapannya bersifat kategorik yang dinyatakan dalam lima kategori, yaitu (1) sangat tidak setuju, (2) tidak setuju, (3) ragu-ragu, (4) setuju dan (5) sangat setuju.

\section{Hasil Uji Statistik}

Pengujian validitas data dalam penelitian ini diukur dengan menggunakan nilai Average Variance Extracted (AVE) yaitu harus dapat lebih besar dari 0,5 untuk dapat dinyatakan valid, tetapi jika nilai korelasinya dibawah 0,5 maka item tersebut dinyatakan tidak valid. Berikut ini merupakan hasil dari nilai AVE Kesejahteraan Psikologis sebesar 0,737, Minat Kewirausahaan sebesar 0,854, Norma Subjektif sebesar 0,714, Pengambilan Risiko Jangka Pendek sebesar 0,702, Persepsi Kontrol Perilaku sebesar 0,819, Sikap sebesar 0,634.

Pengujian reliabilitas data dalam penelitian ini menggunakan cronbach's alpha dan composite reliability untuk dapat menguji reliabilitas. Suatu data dapat dinyatakan reliabel jika hasil dari nilai cronbach's alpha > 0,6 dan juga mempunyai nilai composite reliability lebih besar atau sama dengan 0,7. Berikut ini merupakan hasil dari nilai cronbach's alpha dan composite reliability. Cronbach's Alpha Kesejahteraan Psikologis sebesar 0,821, Minat Kewirausahaan sebesar 0,914, Norma Subjektif sebesar 0,866, Pengambilan Risiko Jangka Pendek sebesar 0,857, Persepsi Kontrol Perilaku sebesar 0,926, Sikap sebesar 0,858. Composite reliability Kesejahteraan Psikologis sebesar 0,893, Minat Kewirausahaan sebesar 0,946, Norma Subjektif sebesar 0,909, Pengambilan Risiko Jangka Pendek sebesar 0,904, Persepsi Kontrol Perilaku sebesar 0,948, Sikap sebesar 0,896.

Hasil analisis $\mathrm{R}^{2}$ menunjukkan variabel minat kewirausahaan memiliki nilai $\mathrm{R}^{2}$ sebesar 0,759 , yang berarti bahwa sebesar 75,9\% variabel minat kewirausahaan dapat dijelaskan oleh variabel sikap, norma subjektif, persepsi kontrol perilaku, kesejahteraan psikologis, pengambilan risiko jangka pendek sedangkan sisanya $(100 \%-75,9 \%)=24,1 \%$ dipengaruhi oleh variabel lainnya diluar penelitian ini seperti locus of control, lingkungan sosial, pendidikan kewirausahaan, dan latar belakang keluarga.

Hasil analisis $Q$-square dihasilkan oleh prosedur blindfolding. Hasil akan memiliki pengaruh yang lemah apabila nilainya 0,02 , pengaruh yang sedang jika 0,15 dan pengaruh yang kuat sebesar 0,35 . Hasil analisis $Q^{2}$ memperoleh nilai $Q^{2}$ sebesar 0,475 . Hal ini menunjukkan bahwa variabel independen berpengaruh kuat dan relevan dalam memprediksi model penelitian. 
Pengujian path coefficients maka dapat diperoleh persamaan dalam penelitian ini yaitu $\mathrm{MK}=0,225 \mathrm{~S}+0,005 \mathrm{NS}+0,327 \mathrm{PKP}+0,209 \mathrm{PRJP}+0,226 \mathrm{KP}$. Variabel Sikap terhadap Minat Kewirausahaan mempunyai pengaruh yang positif yaitu sebesar 0,225 , variabel Norma Subjektif terhadap minat kewirausahaan mempunyai pengaruh yang positif yaitu sebesar 0,005. Variabel Persepsi Kontrol Perilaku terhadap Minat Kewirausahaan mempunyai pengaruh yang positif yaitu sebesar 0,327, Variabel Pengambilan Risiko Jangka Pendek terhadap Minat Kewirausahaan mempunyai pengaruh yang positif yaitu sebesar 0,209, dan variabel Kesejahteraan Psikologis terhadap Minat Kewirausahaan mempunyai pengaruh yang positif yaitu sebesar 0,226.

Pengujian Goodness of Fit dilakukan untuk dapat mengetahui kecocokan dari model yang terdapat dalam penelitian ini. Menurut Tenenhaus (2005), nilai GoF akan dikatakan kecil apabila nilainya 0,1 , dikatakan sedang apabila nilainya 0,25 dan besar jika nilainya 0,36. Untuk mencari GoF dapat digunakan rumus sebagai berikut:

$$
\begin{array}{ll}
\text { GoF } & =\sqrt{\overline{A V E} \times \overline{R^{2}}} \\
\text { GoF } & =\sqrt{0,677 \times 0,759} \\
\text { GoF } & =\sqrt{0,514} \\
\text { GoF } & =0,717
\end{array}
$$

Nilai GoF yang diperoleh hasil perhitungan tersebut ialah sebesar 0,717. Menurut Tenenhaus (2005) nilai tersebut termasuk besar yang berarti variabel bebas dapat memprediksi model secara keseluruhan dengan baik.

Pengujian hipotesis dilakukan untuk mengetahui apakah variabel sikap, norma subjektif, persepsi kontrol perilaku, pengambilan risiko jangka pendek, dan kesejahteraan psikologis berpengaruh signifikan terhadap variabel minat kewirausahaan.

Hasil uji hipotesis pertama menunjukkan variabel sikap yang mengarah ke minat kewirausahaan memiliki nilai $p$ values sebesar 0,020 yang mana nilai ini kurang dari 0,05 , yang artinya bahwa terdapat pengaruh yang positif dan signifikan antara sikap terhadap minat kewirausahaan pada mahasiswa Fakultas Ekonomi Manajemen Universitas Tarumanagara.

Hasil uji hipotesis kedua menunjukkan variabel norma subjektif yang mengarah ke minat kewirausahaan memiliki nilai $p$ values sebesar 0,966 yang mana nilai ini lebih dari 0,05 , yang artinya bahwa tidak terdapat pengaruh antara norma subjektif terhadap minat kewirausahaan pada mahasiswa Fakultas Ekonomi Manajemen Universitas Tarumanagara.

Hasil uji hipotesis ketiga menunjukkan variabel persepsi kontrol perilaku pada yang mengarah ke minat kewirausahaan memiliki nilai $p$ values sebesar 0,046 yang mana nilai ini kurang dari 0,05 , yang artinya bahwa terdapat pengaruh yang positif dan signifikan antara persepsi kontrol perilaku terhadap minat kewirausahaan pada mahasiswa Fakultas Ekonomi Manajemen Universitas Tarumanagara.

Hasil uji hipotesis keempat menunjukkan variabel pengambilan risiko jangka pendek yang mengarah ke minat kewirausahaan memiliki nilai $p$ values sebesar 0,011 yang mana nilai ini kurang dari 0,05 , yang artinya bahwa terdapat pengaruh yang positif dan signifikan antara pengambilan risiko jangka pendek terhadap minat kewirausahaan pada mahasiswa Fakultas Ekonomi Manajemen Universitas Tarumanagara.

Hasil uji hipotesis kelima menunjukkan variabel kesejahteraan psikologis yang mengarah ke minat kewirausahaan memiliki nilai $p$ values sebesar 0,042 yang mana nilai ini 
kurang dari 0,05 , yang artinya bahwa terdapat pengaruh yang positif dan signifikan antara kesejahteraan psikologis terhadap minat kewirausahaan pada mahasiswa Fakultas Ekonomi Manajemen Universitas Tarumanagara.

\section{DISKUSI}

Variabel Sikap terbukti dapat berpengaruh secara signifikan terhadap Minat Kewirausahaan karena hasil nilai t-statistik Sikap sebesar 2,040 yang berarti lebih besar dari 1,96 dan nilai $p$-values Sikap sebesar 0,020 yang berarti lebih kecil dari 0,05, sehingga dapat disimpulkan bahwa Sikap memiliki pengaruh yang signifikan terhadap Minat Kewirausahaan mahasiswa Fakultas Ekonomi Manajemen Universitas Tarumanagara.

Variabel Norma Subjektif tidak berpengaruh secara signifikan namun tetap positif terhadap Minat Kewirausahaan. Norma Subjektif mempunyai nilai t-statistik sebesar 0,042 yang berarti lebih kecil dari 1,96 dan nilai p-values Norma Subjektif sebesar 0,966 yang berarti lebih besar dari 0,05. Sehingga dapat disimpulkan bahwa Norma Subjektif tidak memiliki pengaruh yang signifikan terhadap Minat Kewirausahaan mahasiswa Fakultas Ekonomi Manajemen Universitas Tarumanagara.

Variabel Persepsi Kontrol Perilaku yang mengarah ke minat kewirausahaan memiliki nilai $p$-values sebesar 0,046 yang mana nilai ini kurang dari 0,05, dan nilai t-statistik sebesar 1,998 yang berarti lebih besar dari 1,96 yang artinya bahwa terdapat pengaruh yang positif dan signifikan antara Persepsi Kontrol Perilaku terhadap Minat Kewirausahaan mahasiswa Fakultas Ekonomi Manajemen Universitas Tarumanagara.

Variabel Pengambilan Risiko Jangka Pendek mempunyai nilai t-statistik sebesar 2,556 yang berarti lebih besar dari 1,96 dan nilai $p$ values sebesar 0,011 yang berarti lebih kecil dari 0,05, sehingga dapat disimpulkan bahwa Pengambilan Risiko Jangka Pendek memiliki pengaruh yang signifikan terhadap Minat Kewirausahaan pada mahasiswa Fakultas Ekonomi Universitas Tarumanagara.

Variabel Kesejahteraan Psikologis mempunyai nilai t statistik sebesar 2,335 (lebih besar dari 1,96 dan nilai $p$ values sebesar 0,020 yang mana nilai ini kurang dari 0,05 , yang artinya bahwa terdapat pengaruh yang positif dan signifikan antara Kesejahteraan Psikologis terhadap Minat Kewirausahaan Mahasiswa Fakultas Ekonomi Manajemen Universitas Tarumanagara. pengaruh yang signifikan terhadap Minat Kewirausahaan pada mahasiswa Fakultas Ekonomi Universitas Tarumanagara.

\section{PENUTUP}

${ }^{1)}$ Berdasarkan analisis data dan pembahasan yang telah dilakukan dalam penelitian ini, maka kesimpulannya adalah terdapat pengaruh Sikap dengan Minat Kewirausahaan pada mahasiswa Fakultas Ekonomi Manajemen Universitas Tarumanagara, terdapat pengaruh Norma Subjektif dengan Minat Kewirausahaan pada mahasiswa Fakultas Ekonomi Manajemen Universitas Tarumanagara. terdapat pengaruh Persepsi Kontrol Perilaku dengan Minat Kewirausahaan pada mahasiswa Fakultas Ekonomi Manajemen Universitas Tarumanagara, terdapat pengaruh Pengambilan Risiko Jangka Pendek dengan Minat Kewirausahaan pada mahasiswa Fakultas Ekonomi Manajemen Universitas Tarumanagara, terdapat pengaruh Kesejahteraan Psikologis dengan Minat Kewirausahaan pada mahasiswa Fakultas Ekonomi Manajemen Universitas Tarumanagara. 
${ }^{2)}$ Keterbatasan dalam penelitian ini adalah (1) Keterbatasan waktu dalam penelitian ini sehingga responden yang berpastisipasi dalam penelitian ini hanya berjumlah 100 orang, yang seharusnya dapat lebih dari 100 orang karena melihat banyaknya mahasiswa Fakultas Ekonomi Manajemen Universitas Tarumanagara. (2) Pada penelitian ini hanya menggunakan 5 variabel independen yang terdiri atas Sikap, Norma Subjektif, Kesejahteraan Psikologis, Persepsi Kontrol Perilaku dan Pengambilan Risiko Jangka Pendek, serta 1 variabel dependen yaitu Minat Kewirausahaan. (3) Sampel yang digunakan peneliti hanya mahasiswa Fakultas Ekonomi Manajemen Universitas Tarumanagara, padahal terdapat banyak Fakultas di Universitas Tarumanagara yang dapat diteliti juga.

${ }^{3)}$ Saran-saran yang diberikan dalam penelitian ini adalah (1) Sikap mahasiswa Fakultas Ekonomi Universitas Tarumanagara sudah cukup baik namun mahasiswa harus lebih memikirkan bahwa bisnis tidak hanya untuk kepuasan pribadi semata, namun juga kepuasan pelanggan karena kepuasan pelanggan adalah prioritas bagi pembisnis, dimana dengan tingginya tingkat kepuasan pelanggan maka bisnis pun dapat terus berjalan. (2) Persepsi kontrol perilaku pada mahasiswa Fakultas Ekonomi Universitas Tarumanagara sudah cukup namun mahasiswa harus dapat lebih yakin akan ide bisnisnya dengan mewujudkannya dalam bentuk praktik seperti yang telah diberikan oleh pihak Universitas seperti acara Entrepreneur week. (3) Norma subjektif mahasiswa Fakultas Ekonomi Universitas Tarumanagara sudah baik tetapi dorongan yang diberikan anggota keluarga dan teman memang akan membuat mahasiswa menjadi lebih yakin dan percaya diri dalam mewujudkan ide bisnis mereka. (4) Kesejahteraan psikologis pada mahasiswa Fakultas Ekonomi Universitas Tarumanagara sudah cukup baik tetapi mahasiswa harus lebih berani mengambil keputusan yang berdasarkan pikiran dan pendapatnya, jangan bergantung pada apa yang dikatakan orang, karena kesuksesan hanya didapatkan oleh orang yang mempunyai prinsip dalam bisnisnya. (5) Pengambilan Risiko Jangka Pendek pada mahasiswa Fakultas Ekonomi Universitas Tarumanagara sudah cukup baik tetapi hendaknya mahasiswa harus lebih berani mengambil risiko dengan memberikan ciri khas pada bisnis mereka sehingga berbeda dengan kompetitor demi mencapai kesuksesan bisnis yang diinginkan. (6) Peneliti memberikan saran agar peneliti selanjutnya dapat menambah variabel lain seperti pendidikan kewirausahaan, latar belakang keluarga, lingkungan sosial. (7) Untuk peneliti selanjutnya, peneliti menyarankan untuk memperbesar jumlah sampel, tidak hanya sampel yang berada dalam lingkungan Mahasiswa Fakultas Ekonomi Manajemen Universitas Tarumanagara saja, melainkan peneliti dapat mengambil sampel dari Fakultas yang lain juga.

\section{DAFTAR PUSTAKA}

Ajzen, I., (1991). The Theory of Planned Behavior. Organizational Behavior and Human Decision Processes 50(2), 179-211.

., (2006). Constructing a TPB Questionnaire: Conceptual and Methodological Considerations. Retrieved from http://www.people.umass.edu.

Fishbein, M. \& Ajzen, I. (1975). Belief, Attitude, Intention and Behavior: An Introduction to Theory and Research. Sydney: Addison Wesley Publishing

Gagne, R.M., \& Briggs, L.J. (1979). Principle of Instructional Design, New York: Holt Rinehart and Winston.

Maulana, H. D. (2009). Promosi Kesehatan. Jakarta: Penerbit Buku Kedokteran EGC.

Ramdhani, A. (2011). Penilaian Kinerja. Bandung: PT Sarana Panca Karya Nusa. 
Ismail, V. Y. \& Zain, E. (2008). Peranan Sikap, Norma Subjektif, dan Perceived behavioral control pada Intensi Pelajar SLTA untuk Memilih Fakultas Ekonomi. Jurnal Ekonomi dan Bisnis 5, 12-14.

Kartz,J., \& Gartner. (1998). "Properties of emerging organizations". Academy of Management Review 13 (3): 429-441

Kerlinger, F.N. (1986). Foundations of Behavioral Research, Edisi ke-3, New York: Holt, Rineheart, ad Winston.

Kisker, W., \& Ernst, C. (2015). Influence of the motivation of entrepreneurs on the willingness to take risks. Journal of Interdisciplinary Research 5, 38-40.

Lawton, M. P. (1983). Environment and other determinants of wellbeing in older people. The Gerontologist 23, 349-357.

Ryff, C.D. (1989). Happiness Is Everything, or Is It? Exploration on the Meaning of Psychological Well-Being. Madison: University of Wisconsin.

Subandono, A. (2007). Pengaruh Life Skill Diklat Kimia Produktif dan Prestasi Belajar Diklat Kewirausahaan terhadap Minat Berwirausaha pada Siswa SMK Kimia Industri Theresiana Semarang. Skripsi. FMIPA-UNES.

Tenenhaus, M., Vincenzo, E. V., Yves, M. C., \& Carlo, L. (2005). PLS Path Modeling. Computational Statistics \& Data Analysis, 48(1), 159-205.

Zhang, P., Wang, D. D., \& Owen, C. L. (2015). A Study of Entrepreneurial Intention of University Students. Competitive Research Article, 5(1), 61-82.

Zuckerman, M. (1984) Experience and desire: A new format for sensation seeking scales. Journal of Behavioral Assessment, 6, 101- 114. 